\title{
Photometric study of divine proportion and its correlation with facial attractiveness
}

Ana Paula Lazzari Marques Peron ${ }^{1}$ Imara Castro Morosini' ${ }^{2}$, Keila Rodrigues Correia ${ }^{3}$, Ricardo Moresca ${ }^{4}$, Eros Petrelli $^{5}$

Objective: The aim of this study was to evaluate if there is correlation between perception of facial esthetic and divine proportion, verifying if most attractive faces are closer to and less attractive faces are more distant to this proportion.

Methods: Standard facial photographs (frontal and lateral) in natural head position were taken of a sample of 85 Brazilian Caucasian women, with mean age of 23 years and 9 months. The photographs were evaluated by 5 orthodontists, 5 artists and 5 laymen and were classified, according to their subjective analysis of facial esthetic, in pleasant, acceptable and not pleasant. Frontal photographs were evaluated by divine proportion analysis using the computerized method.

Results and Conclusions: According to subjective analysis the sample consisted $18.8 \%$ of pleasant, $70.6 \%$ of acceptable and $10.6 \%$ of not pleasant faces. After statistical analysis, a lack of agreement was verified in esthetic facial preferences among the three groups of observers. It was also possible to verify that in this research there was no correlation between perception of facial beauty and divine proportion.

Keywords: Divine proportion. Facial analysis. Golden section. Facial esthetic.

${ }^{1}$ Specialist in Orthodontics, Federal University of Paraná (UFPR) - Master student in Orthodontics, Pontifical Catholic University of Paraná(PUCPR) - Professor of the Specialization Course in Orthodontics, University Positivo

${ }^{2}$ Specialist in Orthodontics, UFPR - Master in Dentistry UFPR - Professor of the Specialization Course in Orthodontics, University Positivo

${ }^{3}$ Specialist in Orthodontics, UFPR

${ }^{4}$ Doctor in Orthodontics, FO-USP. Adjunct Professor of UFPR, undergraduate and postgraduate orthodontics. Professor of the Masters Program in Clinical Dentistry at the University Positivo.

5 "In memoriam".
How to cite this article: Peron APLM, Morosini IC, Correia KR, Moresca R, Petrelli E. Photometric study of divine proportion and its correlation with facial attractiveness. Dental Press J Orthod. 2012 Mar-Apr;17(2):124-31.

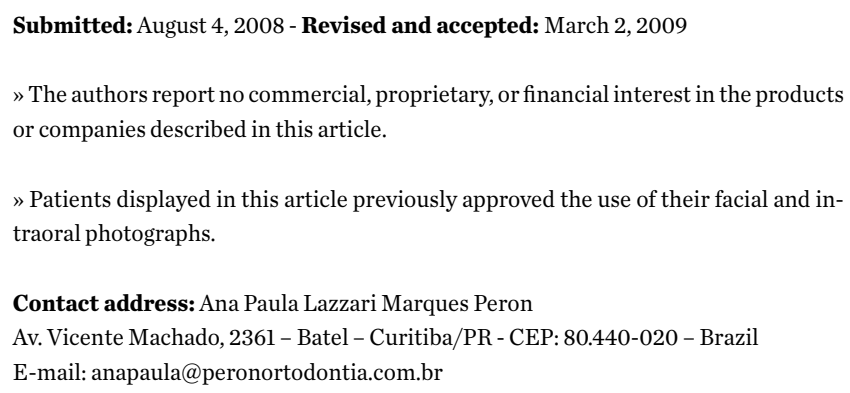




\section{INTRODUCTION}

It's known that the main reason that moves a patient to seek orthodontic treatment is the search for improved facial esthetics ${ }^{10,23}$ and, in this regard, evaluation of soft tissue is of the utmost importance for orthodontic planning. ${ }^{1}$ So, as the orthodontists have increased their ability to modify the face, the need to understand what is beautiful or not has been intensified ${ }^{1}$. This perspective requires orthodontists to approach the expectations of their patients, considering facial esthetic and the smile as the main treatment objective. ${ }^{23}$

Due to limitations in the evaluation of soft tissue through cephalometric analyses and the complexity involving facial esthetics, several researchers began to advocate the use of numerical and proportional facial analysis directly on the face of patients ${ }^{1}$ or through the study of photographs. , $3,7,10,11,17,20,25,27^{2}$

The direct clinical examination of the face of patients has limitations as the sensitivity of some tissues and the compression of others, that lead to technical errors ${ }^{2}$ and makes measuring more difficult, and also does not allow future diagnostic comparisons or researches. ${ }^{22}$ Thus, the photograph becomes a basic tool for facial analysis, ${ }^{2}$ having the advantages of not exposing patients to ionizing radiation, being of low cost and providing a better assessment of facial harmony. ${ }^{5}$ However, in order to allow for the use of this method in a scientific way, the standardization for obtaining photographs became necessary. ${ }^{10,15,22}$

With this purpose, the Natural Head Position (NHP) has been employed for being a standardized and reproducible position ${ }^{7,16}$ in an erect posture with eyes focused on a point located at the same level, implying a horizontal visual axis, which can be more effectively achieved by using a mirror. ${ }^{4}$

Because of the variations that exist between genders and ethnic, racial and demographic differences, the use of proportional assessments stands out for the study of facial esthetics rather than absolute values pre-established as is observed in numerical facial analysis. ${ }^{12}$ In this way, facial proportion analyses emerged, including the divine proportion.

Divine proportion applications, which can also be called the golden section, are known since antiquity. This theory states that humans, for some reason, has esthetic preference for objects, geometric figures, buildings, among others, presenting this proportion or at least very close to it. ${ }^{8}$ This relationship can be observed on the face and in the relationship between the smile and face ${ }^{14}$ therefore, several authors have used and advocated the use of the golden section in facial ${ }^{8,19,25}$ and cephalometric $^{8,9,11,19,25,26}$ analyses.

The golden section is obtained through asymmetric division of a line in order to maintain a proportion such that the largest segment is to smallest as well as the sum of both is for the largest. ${ }^{26}$ The largest portion of this line is always 1,618 times the smaller size and this corresponds to 0,618 times the length of larger. ${ }^{25}$

In the 80 's, Ricketts ${ }^{24,25}$ was a great divine proportion enthusiast, studying and publicizing its connection with facial harmony. Since then, researches using this concept were developed in order to individualize orthodontic diagnosis., ${ }^{919}$

The divine proportion does not adhere to populational means obtained in researches carried out in specific groups. In this way, it can be applied to anyone regardless of gender, age, ethnicity, race and demographic differences. The easiness and rapidity of its execution are other advantages attributed to this analysis. In this way, for the development of this research we employed the divine proportion facial analysis in frontal facial photographs, taking as reference the studies of Ricketts ${ }^{25}$ in 1982.

Therefore, this work aims to contribute to orthodontic diagnosis through facial analysis, proposing to:

1. Characterize the sample through subjective analysis of facial esthetics performed by a board of evaluators, in esthetically unpleasant, esthetically acceptable and esthetically pleasing.

2. Verify if there is a correlation between orthodontists, lay people and visual artists on the evaluation of facial esthetics and if an intergroup lack of agreement is found, check what is the trend of judgement between the three different areas of professional activity composing the board of evaluators.

3. Check the possible association between the perception of facial beauty and the divine proportion, in this way determining, if the subjects considered most attractive present this proportion and the less attractive are different from it. 


\section{MATERIAL AND METHODS Material}

The sample used for the preparation of this study comprised 85 randomly selected women, Brazilian, Caucasian, with an average age of 23 years and 9 months ranging from 18 years and 7 months to 30 years and 3 months, which have not undergone any type of plastic surgery in the head and neck region and that were willing to voluntarily participate in this survey.

Only women were selected in order to characterize and individualize the sample. Furthermore, this work was part of a series of surveys conducted to study feminine facial esthetics through many facial analyses, both numeric and proportional.

A prior orthodontic treatment was not an exclusion factor for the participation in this research, and occlusal issues were not considered in the selection of the sample, because good facial esthetics may be associated with malocclusions and normal occlusions. ${ }^{5}$ Neither was the objective of this survey to relate facial esthetics with the occlusion.

The photographic records of the sample were made using: Canon EOS Rebel XT digital camera, macro lens 100/35 mm circular flash Canon Vivitar tripod, a plumb and line as true vertical reference, a rectangular mirror, a projection white screen for background standardization and a strip of fabric to hold the hair.

The program used for the method was the Radiocef Studio ${ }^{\circledR}$ (Radio Memory Ltda., Belo Horizonte, Brazil) in a HP Pavilion dv6000 computer.

\section{METHOD}

\section{Photographic record}

Standardized frontal and lateral facial photographs were carried out. The individuals were photographed seated, maintaining an upright position, natural and normal, with both arms hanging freely along body, corresponding to the natural head position (NHP) of Broca, ${ }^{7}$ and this is the position in which the individual remains daily. ${ }^{29}$ To assist in achieving the NHP, a mirror was positioned on the height of the eyes of the individuals so that they could fix the gaze on their pupils. A projection white screen was placed for the background, in such a way that the environment would not influence the evaluation, and as a true vertical reference, a plumbline ${ }^{16}$ was tied to the screen support so that it was visible in the photograph.
The camera remained fixed on a tripod. The focal distance was $1.70 \mathrm{~m}$, the shutter speed $1 / 200$ and the lens aperture F29. As a source of light, a circular flash was used. In order to view all points of reference for the proposed facial analysis (in special Trichion) a hairband was used on all participants.

All photographs were printed in color, matte paper, $10 \mathrm{~cm} \mathrm{x} 15 \mathrm{~cm}$ in size, at the same time and in the same photo lab, QLab standard (Kodak international standard quality).

No method was used to measure the distortion between the actual size of the face and the size of the photo, since only proportional measures were studied and in this way, size variations makes no difference in the final result. ${ }^{25}$

\section{Sample classification method}

For sample classification by facial esthetics subjective analysis, a board was selected consisting of 15 individuals divided into three groups of professional activity, as follows: 5 orthodontists; 5 visual artists, professors from the Faculty of Fine Arts of Paraná; 5 lay persons to dental area and not involved in any artistic activity, all residents in the city of Curitiba.

Each evaluator received a set of 170 photos corresponding to frontal and sides shots of 85 individuals from the sample, with each one receiving just one score.

The participants of the board were instructed to analyse all photographs at the same time and to classify individuals according to their own criteria for facial esthetics, giving scores between 1 and $9,{ }^{15,22}$ considering the score 1 the lowest and 9 the greater degree of attractiveness.

From these scores, the sample was divided into three groups: Esthetically unpleasant, esthetically acceptable and esthetically pleasant. ${ }^{15,22}$

Individuals with average grades 1, 2, 3 and 4 were classified as esthetically unpleasant (Group I); with average grades 5 and 6 , as esthetically acceptable (Group II) and with average grades 7, 8 and 9 as esthetically pleasant (Group III).

\section{Analysis of frontal facial divine proportion}

The frontal facial photos were analyzed through the program Radiocef Studio $2^{\circledR}$ on a flat panel monitor. The analysis of frontal facial divine proportion was created through the Mixcef 
tool provided by the software, where all necessary points are generated, and then 8 vertical and 3 lateral segments were determined, and through mathematical expressions gave rise to 8 factors. These were numbered of " $\Phi 1$ to $\Phi 8$ " and corresponded to 6 vertical measures of frontal facial divine proportion and 2 transversal, which will be described later.

\section{Photometric reference points}

Photometric employed points (Fig 1) were proposed by Ricketts ${ }^{25}$ in 1982:

TRI - (Trichion) - point determined by the hairline on the forehead midpoint in young subjects;

LCr - (Lateral Canthus right) - point located in the lateral corner of right eye;

LCl - (Lateral Canthus left) - point located in the right corner of left eye;

LNr - (Lateral Nasal right) - point located on the external portion of the right wing of the nose;

LNl - (Lateral Nasal left) - point located on the external portion of the left wing of the nose;

ALr - (Right Alar Edge) - point located on the top edge of the right wing curvature of the nose;

ALl - (Left Alar Edge) - point located on the top edge of the left wing curvature of the nose;

CHr - (Right Chilion) - point located in the outermost portion of the labial commissure, in the right angle of the mouth;
CHI - (Left Chilion) - point located in the outermost portion of the labial commissure, in the left angle of the mouth;

ME - (Tegumentary Menton) - point located on tegumentary menton in correlation with the osseous menton point.

Due to peculiarities relevant to the program used, in the vertical frontal facial analysis all points were orthogonally projected over the true vertical line (TVL) and proportional measures were performed on it by the point to point distance. For the proportions that involved lines formed by the union of two points, the midpoint between them was found and then was projected over the TVL (Fig 1).

\section{Vertical frontal face measures of divine proportion}

The vertical frontal face analysis of divine proportion was performed employing a selection of measurements proposed by Ricketts, ${ }^{25} 1982$ (Fig 2).

$\Phi$ 1. Trichion - Lateral Canthus // Lateral Canthus - Menton;

$\Phi$ 2. Menton - Alar Edge // Alar Edge - Trichion;

$\Phi$ 3. Lateral Canthus - Alar Edge // Alar Edge Menton;

$\Phi$ 4. Chilion - Menton // Chilion - Lateral Canthus;

$\Phi$ 5. Alar Edge - Chilion// Lateral Canthus - Alar Edge;

Ф 6. Alar Edge - Chilion // Chilion - Menton.

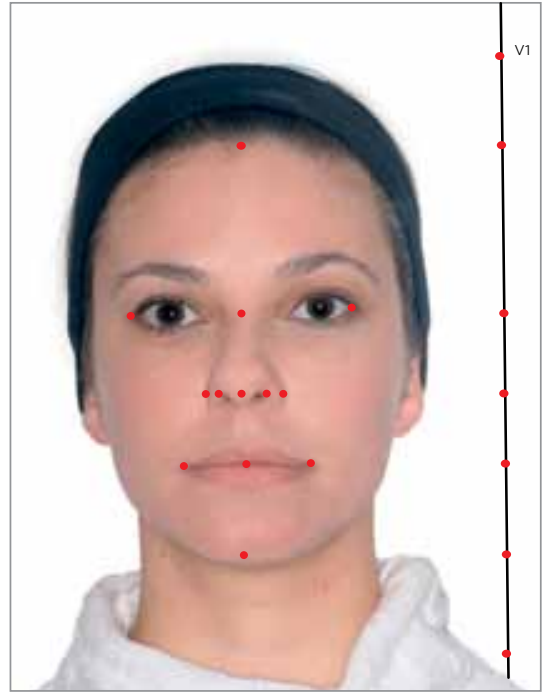

Figure 1 - Reference points used in the analyses of the frontal facial divine proportion. The TVL was determined by the union of the points $\mathrm{V} 1$ and $\mathrm{V} 2$.

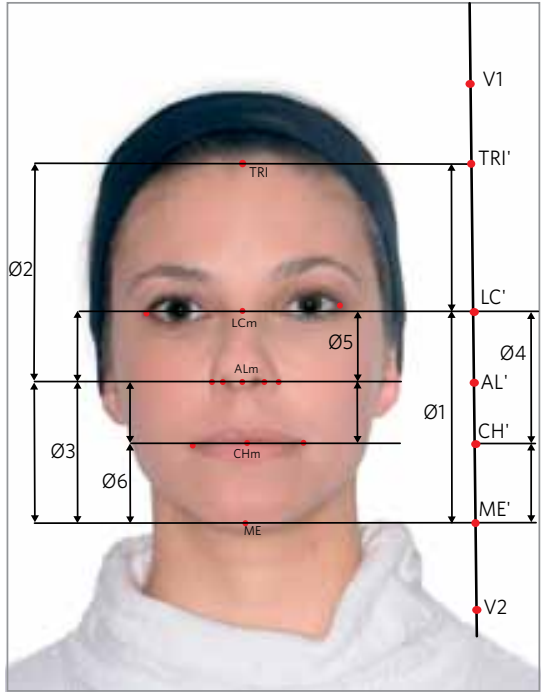

Figure 2 - Measurement of the vertical frontal facial divine proportion.

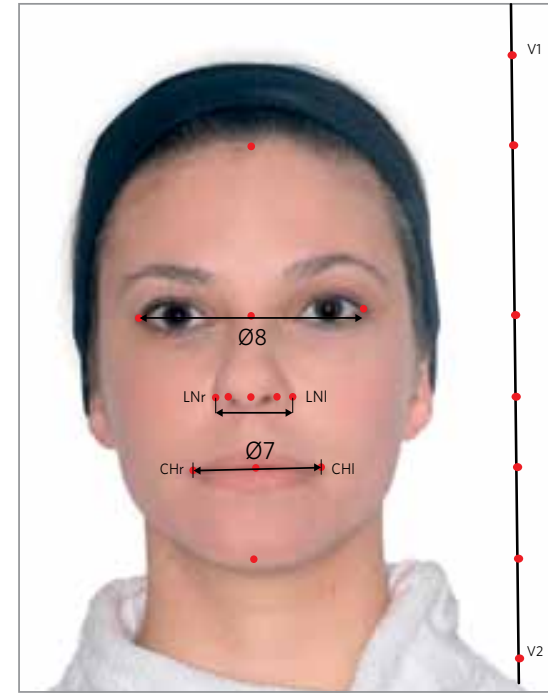

Figure 3 - Measurement of the transversal frontal facial divine proportion. 


\section{Transversal frontal face divine proportion}

For the analysis of the divine proportion in transversal frontal face photographs two variables proposed by Ricketts ${ }^{25}$ were verifyed (Fig 3 ).

Ф7. Right Lateral Nasal - Left Lateral Nasal // Right Chilion - Left Chilion;

$\Phi$ 8. Right Chilion - Left Chilion // Right Lateral Canthus - Left Lateral Canthus.

To verify if quantities analyzed were or were not in the divine proportion, we used the method described by Gil and Medici Filho, ${ }^{9}$ that is based on the following concept: A couple of measures $(a, b)$ is in the golden ratio if $a / b=b /(a+b)$, where $a<b$. The difference between ratio $|a / b=b /(a+b)|$ is called delta and this will be null when the pair of measures is in divine proportion.

\section{Statistical analysis}

Through statistical analysis the information corresponding to the sample, mean, standard deviation, minimum and maximum value observed, median and coefficient of variance, was obtained. The level of agreement among the three groups of observers on subjective analysis of facial esthetics was calculated by the Kappa index and by the percentage of evaluators in

Table 1 - Subjective concept of facial esthetics.

\begin{tabular}{llcc} 
Concept & & Number & Percentage \\
\hline Unpleasant & (Group I) & 16 & 18,8 \\
Acceptable & (Group II) & 60 & 70,6 \\
Pleasant & (Group III) & 09 & 10,6 \\
TOTAL & & 85 & 100,0 \\
\hline
\end{tabular}

agreement, always by pairwise comparison of groups.

For the statistical evaluation of frontal facial analysis of divine proportion, the median value was used because the coefficient of variation found was high. Therefore, a non-parametric test for paired data was applied, in this case, the Kruskal-Wallis test. The significance level used was less than $5 \%(\mathrm{p}<0,05)$.

The reliability of measures used (error of method evaluation) was analyzed by selecting, at random, 20 photographs in which new tracings were performed with one week interval. For casual error analysis, we applied the Dahlberg's formula. For the evaluation of systematic error, the data obtained was subjected to the non-parametric Wilcoxon test.

\section{RESULTS}

The results obtained were subjected to statistical analysis and are presented in Tables 1, 2, 3 and 4 .

\section{DISCUSSION}

Despite the eminently subjective character for beauty perception, ${ }^{1,6,13,18}$ it becomes necessary to acknowledge and study facial esthetics, to bear in mind the concept of "normality" serving as a guide during orthodontic treatment planning. It is in this sense that extensive research has been developed, seeking to find standard average values, both numeric and proportionate, to obtain an objective facial analysis.

This survey was conducted in order to evaluate the facial pleasantness and its relationship with divine proportion in frontal images. With the results of subjective analysis of facial esthetics it was observed that $18.8 \%$ of the sample studied was classified as

Table 2 - Kappa coefficient of agreement between observers.

\begin{tabular}{ccccc} 
& Observers & & \% Agreement & Kappa \\
\hline Lay & $X$ & Visual Artists & 41.2 & 0.2026 \\
Lay & $X$ & Orthodontists & 18.8 & Slight \\
Visual Artists & $X$ & Orthodontist & 45.9 & -0.0507 \\
\hline
\end{tabular}

Table 3 - General average score by different groups of observers.

\begin{tabular}{|c|c|c|c|c|c|c|c|c|}
\hline \multirow{2}{*}{ Mean score } & \multicolumn{2}{|c|}{ Lay } & \multicolumn{2}{|c|}{ Visual Artists } & \multicolumn{2}{|c|}{ Orthodontists } & \multicolumn{2}{|c|}{ Total } \\
\hline & n & $\%$ & n & $\%$ & $n$ & $\%$ & $n$ & $\%$ \\
\hline $1,2,3,4$ & 26 & 30.6 & 21 & 24.7 & 06 & 7.1 & 53 & 20.8 \\
\hline 5,6 & 55 & 64.7 & 53 & 62.3 & 58 & 68.2 & 166 & 65.1 \\
\hline $7,8,9$ & 04 & 4.7 & 11 & 13.0 & 21 & 24.7 & 36 & 14.1 \\
\hline TOTAL & 85 & 100.0 & 85 & 100.0 & 85 & 100.0 & 255 & 100.0 \\
\hline
\end{tabular}


Table 4 - Descriptive statistics of facial analyses factor of divine proportion in the studied groups.

\begin{tabular}{|c|c|c|c|c|c|c|c|}
\hline Data & $\mathbf{n}$ & Mean & $\begin{array}{l}\text { Standard } \\
\text { deviation }\end{array}$ & Min & Max & Median & p value ${ }^{*}$ \\
\hline Ф1) TRI-LC // LC-ME" & 85 & 0.08 & 0.08 & -0.09 & 0.28 & 0.08 & 0.627 \\
\hline - Unpleasant & 16 & 0.07 & 0.11 & -0.09 & 0.24 & 0.08 & \\
\hline - Acceptable & 60 & 0.08 & 0.08 & -0.09 & 0.28 & 0.08 & \\
\hline - Pleasant & 09 & 0.10 & 0.06 & 0.01 & 0.19 & 0.10 & \\
\hline Ф 2) $M E "-A L / / A L-T R I$ & 85 & 0.04 & 0.08 & -0.14 & 0.24 & 0.04 & 0.392 \\
\hline - Unpleasant & 16 & 0.05 & 0.10 & -0.09 & 0.24 & 0.06 & \\
\hline - Acceptable & 60 & 0.04 & 0.07 & -0.14 & 0.18 & 0.05 & \\
\hline - Pleasant & 09 & 0.00 & 0.07 & -0.09 & 0.10 & -0.01 & \\
\hline Ф 3) LC-AL // AL-ME" & 85 & -0.13 & 0.09 & -0.29 & 0.14 & -0.13 & 0.506 \\
\hline - Unpleasant & 16 & -0.14 & 0.10 & -0.29 & 0.01 & -0.15 & \\
\hline - Acceptable & 60 & -0.13 & 0.09 & -0.27 & 0.14 & -0.14 & \\
\hline - Pleasant & 09 & -0.10 & 0.08 & -0.24 & 0.03 & -0.11 & \\
\hline Ф 4) $\mathrm{CH}-\mathrm{ME} " / / \mathrm{CH}-\mathrm{LC}$ & 85 & 0.07 & 0.06 & -0.09 & 0.22 & 0.06 & 0.510 \\
\hline - Unpleasant & 16 & 0.07 & 0.08 & -0.07 & 0.21 & 0.07 & \\
\hline - Acceptable & 60 & 0.07 & 0.06 & -0.09 & 0.22 & 0.06 & \\
\hline - Pleasant & 09 & 0.05 & 0.07 & -0.04 & 0.17 & 0.04 & \\
\hline Ф 5) $\mathrm{AL}-\mathrm{CH} / / \mathrm{LC}-\mathrm{AL}$ & 85 & 0.19 & 0.17 & -0.27 & 0.49 & 0.19 & 0.672 \\
\hline - Unpleasant & 16 & 0.19 & 0.15 & -0.03 & 0.43 & 0.17 & \\
\hline - Acceptable & 60 & 0.19 & 0.17 & -0.27 & 0.49 & 0.19 & \\
\hline - Pleasant & 09 & 0.14 & 0.17 & -0.14 & 0.35 & 0.15 & \\
\hline Ф 6) $\mathrm{AL}-\mathrm{CH} / / \mathrm{CH}-\mathrm{ME} "$ & 85 & 0.04 & 0.10 & -0.23 & 0.25 & 0.05 & 0.909 \\
\hline - Unpleasant & 16 & 0.03 & 0.08 & -0.12 & 0.15 & 0.05 & \\
\hline - Acceptable & 60 & 0.04 & 0.11 & -0.23 & 0.25 & 0.05 & \\
\hline - Pleasant & 09 & 0.03 & 0.13 & -0.23 & 0.24 & 0.05 & \\
\hline Ф 7) LNr-LNI // CHr-CHI & 85 & 0.12 & 0.07 & -0.02 & 0.30 & 0.11 & 0.104 \\
\hline - Unpleasant & 16 & 0.13 & 0.07 & 0.00 & 0.25 & 0.13 & \\
\hline - Acceptable & 60 & 0.12 & 0.07 & -0.02 & 0.30 & 0.12 & \\
\hline - Pleasant & 09 & 0.08 & 0.05 & 0.00 & 0.16 & 0.08 & \\
\hline Ф 8) $\mathrm{CHr}-\mathrm{CHI} / / \mathrm{LCr}-\mathrm{LCl}$ & 85 & -0.11 & 0.05 & -0.20 & 0.00 & -0.12 & 0.528 \\
\hline - Unpleasant & 16 & -0.12 & 0.06 & -0.20 & 0.00 & -0.12 & \\
\hline - Acceptable & 60 & -0.11 & 0.05 & -0.20 & -0.01 & -0.12 & \\
\hline - Pleasant & 09 & -0.10 & 0.05 & -0.19 & -0.04 & -0.09 & \\
\hline
\end{tabular}

NOTE: For very high s.d. it is recommended to use the median. * Kruskal-Wallis.

esthetically unpleasant, $70.6 \%$ esthetically acceptable and $10.6 \%$ esthetically pleasing, in this way we verified the prevalence for the acceptable standard (Table 1).

These findings corroborate with other researches demonstrating the preponderance of the acceptable pattern ${ }^{15,22}$ in the samples. The smallest group found in this work was the esthetically pleasant, making evident the rigidity of esthetic ideal imposed by today's society.

To esthetically classify sample in a reliable manner, reducing individual influences, we sought to select a larger and more heterogeneous board as possible, composed by evaluators belonging to different areas of professional activity. This selection followed the tendency found in the literature, where we found that several authors select orthodontists, visual artists, laypersons or the combination of two, or even three groups, ${ }^{5,15,18,20}$ to analyze the degree of facial attractiveness of the samples.

In assessing the degree of correlation between the three groups that composed the board of observers, we noticed the low correlation in esthetic conception between them. The lowest correlation occurred between 
laypersons and orthodontists being considered poor by the Kappa index (-0.0507), which indicates a low percentage of agreement (18.8\%).

Between laypersons and artists the correlation was considered slight $($ Kappa $=0.2026)$ with $41.2 \%$ of agreement and, finally, between visual artists and orthodontists we observed a regular result (Kappa $=$ 0.2795) representing $45.9 \%$ of agreement (Table 2 ).

In this way, it highlights the need to take into account the patient's own expectations in relation to facial esthetics, since his appreciation of beauty can differ from that of orthodontists.

The results obtained were similar to those found in other researches, ${ }^{3,15,17,18}$ which suggest that the criteria of the evaluators are eminently subjective, where the more diverse the area of expertise of the evaluators the lower the correlation between them.

In this paper, it may be noted that the group of laypeople had a tendency to be more demanding in facial esthetic judgment, the second group was of visual artists and the less critical were the orthodontists (Table 3).

The discrepancy found is due to, probably, the fact that the professionals dealing with the face or with the study of art have in mind the facial limitations and a greater understanding of the balance between the parts, where, while examining an individual, they look for a good relationship between parts and not just the initial esthetic aspect, as occurs with the lay. It was therefore verified that if the observers were more specialized in the study of the face greater was their degree of tolerance in relation to the assessment of facial esthetic. ${ }^{20,21,28}$

It is remembered that more conclusive results regarding the assessment of the degree of correlation between the observers, as well as the tendency of esthetic judgment between the different areas of professional activity, the ideal would be to use a board consisting of a number of evaluators larger than the one employed in this study.

Regarding to the frontal facial analysis of divine proportion, results differ from those obtained by Ricketts, ${ }^{25}$ in 1982. Statistically, none of the evaluated relations presented divine proportions (Table 4 ), despite some measures used, such as the $\Phi 2$, for the pleasant group presented median values close to the zero delta value, the eight evaluated ratios are away from this value, in addition none of them has exactly this number.

An important factor to be emphasized is that when Ricketts ${ }^{25}$ performed his studies he employed the golden compass directly over the facial photographs, which probably, allows to obtain only approximate values. In this research, a analysis of divine proportion was developed through a computer program, establishing and marking each photometric points of reference, in this way we obtained exact measurements. Another important factor, is that in this work standardized facial photographs were used and, in contrast, the author ${ }^{25}$ performed his measures in photographs obtained from magazine covers.

In the descriptive statistic analysis it was noticed that there was no significant difference in the medians of the divine proportion deltas between groups esthetically unpleasant, esthetically acceptable and esthetically pleasant, demonstrating that for the studied sample, "pleasant" individuals did not tend to have higher values in golden proportion than "acceptable" or "unpleasant" individuals.

Results corroborate with previous studies, ${ }^{3,17}$ that also did not find significant difference in the medians of the deltas within the categories of pleasantness, noting that individuals regarded as more attractive do not have more measures in golden proportion than those considered less attractive.

In this way, it may be noted that faces considered beautiful may not display the divine proportion and vice versa, ${ }^{2}$ and therefore not always facial esthetic improvement at the end of treatment should be related to the patient's facial measurements proximity to the golden section. ${ }^{27}$

On the other hand, presented results disagree to those found by Santos ${ }^{26}$ and Kawakami, et al. ${ }^{11}$ These authors observed that the human face has numerous structures in golden proportion relating themselves in many ways giving esthetic balance. $\mathrm{Gil}^{8}$ affirms that divine proportion is a translation of "good sense" or "common sense" in beauty evaluation, advocating that this analysis should be based on the measures proposed by Ricketts, ${ }^{25}$ in 1982.

We emphasize that facial analysis is essential in orthodontics and orthognathic planning, nevertheless, the evaluation of beauty seems to be mostly 
subjective and personal. In this way, one should take into consideration the expectations and the esthetic concept of their own patient, associating, of course, to the orthodontic scientific knowledge on human face. It is believed that individual facial esthetic characteristics, and not only proportions, give major influence in beauty perception and, as in cephalometric analyses, facial analysis of divine proportion also have certain limitations. ${ }^{27}$

Therefore, if divine proportion will be employed in orthodontic or orthognathic planning, this should be employed only as a guideline working together with other methods already established.

\section{CONCLUSIONS}

With the development of this study, we can conclude that:

1. Subjective analysis of facial esthetic classified the studied sample in $18.8 \%$ as esthetically unpleasant, $70.6 \%$ as esthetically acceptable and $10.6 \%$ as esthetically pleasant, in this way verifing the prevalence of the acceptable standard.

2.A low grade of agreement in facial esthetic evaluation was observed between the three groups of observers in this research,. The more skilled in facial study was the evaluator, higher was the grade of tolerance on esthetic evaluation, being the lay group the most demanding and the orthodontists the less critical.

3.There was no statistically significant difference in delta medians of divine proportion between groups esthetically unpleasant, esthetically acceptable and esthetically pleasant.

In this way, it could be verified that in this research there was no association between the perception of facial beauty and divine proportion.

\section{REFERENCES}

1. Annett GW, Bergman RT. Facial keys to orthodontic diagnosis and treatment planning. Part I. Am J Orthod Dentofacial Orthop. 1993;103(4):229-312.

2. Backer BW, Woods MG. The role of the divine proportion in the esthetic improvement of patients undergoing combined orthodontic/orthognathic surgical treatment. Int J Adult Orthodon Orthognath Surg. 2001;16(2):108-20.

3. Bertollo RM. Avaliação das proporções faciais, em fotografias frontais e laterais, de homens e mulheres com harmonia facial, em relação às proporções divinas [tese]. Porto Alegre (RS): Pontifícia Universidade Católica; 2002.

4. Cooke MC, Wei SHY. The reproducibility of natural head posture: a methodological study. Am J Orthod Dentofacial Orthop. 1988;93(4):280-8.

5. Cox NH, Van der Linden FPGM. Facial harmony. Am J Orthod. 1971;60(2):175-83.

6. Czarnecki ST, Nanda RS, Currier GF. Perceptions of a balanced facial profile. Am J Orthod Dentofacial Orthop. 1993;104(2):180-7.

7. Ferrario VF, Sforza C, Miani A, Tartaglia G. Craniofacial morphometry by photographic evaluations. Am J Orthod Dentofacial Orthop. 1993;103(4):327-37.

8. Gil CTLA. Proporção áurea craniofacial. 1a ed. São Paulo: Editora Santos, 2001.

9. Gil CTLA, Médici EF. Estudo da proporção áurea na arquitetura craniofacial de indivíduos adultos com oclusão normal, a partir de telerradiografias axiais, frontais e laterais. Ortodontia. 2002;35(2):69-85.

10. Herzberg BL. Facial esthetics in relation to orthodontic treatment. Angle Orthod. 1952;22(1):3-12

11. Kawakami S, Tsukada S, Hayashi H, Takada Y, Koubayashi S. Golden proportion for maxillofacial surgery in orientals. Ann Plast Surg. 1989;23(5):417-25.

12. Koury E, Epker BN. Maxilofacial esthetics: anthropometrics of the maxilofacial region. J Oral Maxillofac Surg. 1992;50(8):806-20.

13. Langlade ML. Análise da estética. In: Diagnóstico ortodôntico. 1a ed. São Paulo: Ed. Santos; 1993. p. 128-60

14. Levin El. Dental esthetics and the golden proportion. J Prosthet Dent. 1978;40(3):244-52.

15. Martins LF. Análise fotométrica em norma frontal, de adultos, brasileiros, leucodermas, não tratados ortodonticamente, classificados pela estética facial [dissertação]. São Bernardo do Campo (SP): Universidade Metodista de São Paulo; 2001.
16. Moorrees C F. Natural head position: a revival. Am J Orthod Dentofacial Orthop. 1994;105(5):512-3.

17. Morihisa O. Avaliação comparativa entre agradabilidade facial, proporção áurea e padrão facial [dissertação]. São Bernardo do Campo (SP): Universidade Metodista de São Paulo; 2006.

18. Okuyama CC, Martins DR. Preferência do perfil facial tegumentar, em jovens leucodermas, melanodermas e xantodermas de ambos os sexos, avaliados por ortodontistas, leigos e artistas plásticos. Ortodontia. 1997;30:6-18.

19. Petrelli NE, Baptista JM. Análise da proporção divina. In: Fundamentos em cefalometria clínica. 1a ed. Curitiba: Editek; 1997. p. 254-63.

20. Peck H, Peck S. A concept of facial esthetics. Angle Orthod. 1970;40(4):284-318.

21. Phillips C, Trentini CJ, Douvartzidis N. The effect of treatment on facial attractiveness. J Oral Maxilofac Surg. 1992;50(6):590-4.

22. Reis SAB. Análise facial numérica e subjetiva do perfil e análise da relação oclusal sagital de brasileiros, adultos, leucodermas não tratados ortodonticamente [dissertação]. São Bernardo do Campo (SP): Universidade Metodista de São Paulo; 2001.

23. Reis $S A B$, Capelozza Filho L, Claro CAA. Análise facial subjetiva. Rev Dental Press Ortod Ortop. 2006;11(5):159-72

24. Ricketts RM. The golden divider. J Clin Orthod. 1981;15(11):752-9.

25. Ricketts RM. The biologic significance of the divine proportion and the Fibonacci series. Am J Orthod. 1982;81(5):351-70.

26. Santos JE. Estudo da proporção áurea em fotografias faciais de indivíduos com oclusão normal [dissertação]. São Bernardo do Campo (SP): Universidade Metodista de São Paulo; 2003.

27. Shell TL, Woods MG. Facial aesthetics and the divine proportion: a comparison of surgical and non-surgical Class II treatment. Aust Orthod J. 2004;20(2):51-63.

28. Spyropoulos MN, Halazonetis DJ. Significance of the soft tissue profile attractiveness. Am J Orthod Dentofacial Orthop. 2001;119(5):469-71.

29. Viazis AD. Cefalometria. In: Atlas de ortodontia avançada: um guia para a eficiência clínica. São Paulo; Ed. Santos; 1999. p. 9-14. 